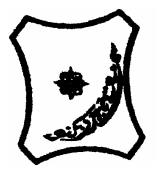

Bayero Journal of Pure and Applied Sciences, 6(2): 35 - 40

Received: March 2013

Accepted: September 2013

ISSN $2006-6996$

\title{
HERITABILITY OF SOME QUANTITATIVE CHARACTERS IN FIVE VARIETIES OF MAIZE (ZEA MAYS L.,) UNDER THE INFLUENCE OF VARIOUS LEVELS OF NITROGEN
}

\author{
* Magashi, A. I., Wailare, M.A. and Madaki, Abubakar Sarki \\ Department of Crop Science, Kano University of Science and Technology, Wudil, Kano, Nigeria \\ *Correspondence author: magashi2@mail.ru, magashi2@yahoo.com
}

\begin{abstract}
A field experiment was conducted at the Kano University of Science and Technology Wudil teaching and research farm during the 2010 and 2011 rainy seasons. Five varieties of maize were studied to estimate components of genetic variance and heritability of some quantitative characters that might exist among them, under the influence of different levels of Nitrogen fertilizer. The experiment was laid out in a randomized complete block design, and replicated three times. The genotype $\times$ different levels of nitrogen fertilizer $(G \times N)$ influenced the expression of the ear height and yield component. Analysis of variance for plant height revealed highly significant differences among varieties with genotypic coefficient of variation (1.67\%) which is smaller than the phenotypic coefficient of variation (1.72\%). The estimate of broad-sense heritability was high (0.79), thus showing the presence of considerable amount of genetic variation in total phenotypic variation. While the analysis of variance for ear height showed highly significant differences among genotypic coefficient of variation (0.93\%) which is smaller than the phenotypic coefficient of variation $(1.05 \%)$. The estimate of broad-sense heritability was high $(0.49)$ indicating the presence of considerable amount of genetic variation in total phenotypic variation. The results confirmed the findings of other researchers on high heritability for plant height. Analysis of variance for grain yield per plot showed greater Genotypic variance than the environmental variance with genotypic coefficient of variation (5.33\%) which is smaller than the phenotypic Coefficient of variation (6.24\%)and the estimate of broad sense heritability $(0.78)$ was moderately high.
\end{abstract}

Keywords: Heritability, variation, ear height, genes.

INTRODUCTION

Maize (Zea mays L.) is one of the most important food crops worldwide. After wheat and rice, maize is one of the major cultivated cereals in Nigeria; it is used as human food, livestock feed and as raw material for industrial uses such as manufacture of vegetable oil, commercial starch and pulp for rough material paper (Azanza,1996), (Ife Journal of Agric, 1982).

Nigeria is one of the developing countries of the world; the majority of its populace depends on plant carbohydrate sources. Maize as a cereal crop contains a high percentage of carbohydrate. However, the amount of maize produced in Africa does not commensurate with the carbohydrate requirement. In line with this therefore, maize seed production needs to be expanded in order to meet the carbohydrate requirements. This study was undertaken with the aim of selecting variety (ies) with uniform ear height under optimum nutrient requirement for extensive mechanized maize production.

Many researchers have experimentally demonstrated that grain yield of maize is contingent upon genotype and growth conditions (Gozubenli et. al, 2001 and Ha, 2007). An extensive maize breeding programme was started at International Center for the Improvement of Maize and Wheat CIMMYT with head quarter at Mexico city, Mexico some years ago, aimed at producing superior hybrids with a short growing season(early maturing), high yield and tolerant to draught.
The aim of the study was to estimate genetic variances for some quantitative characters under the influence of different levels of nitrogen fertilizer and to estimate their heritability. The estimation of heritability of some genetic traits is necessary in order to provide successful selection for certain traits. Therefore, the discovery of genetic variability of different maize quantitative characters (yield component etc) can be significantly altered by selection. Hence an auspicious selection and breeding for these traits is facilitated by the abundant genetic variability found in it (Eltahir et. al., 2003; Kumari et. al., 2006; Pal et. al., 1986 and Sujiprihati, et. al., 2005)

\section{MATERIALS AND METHODS}

The four different varieties used in these studies were obtained from Institute of Agricultural Research ABU Zaria, Nigeria and they comprised: Sammaz 17, Sammaz 18, sammaz 20, and sammaz 28. These are extra early maturing, intermediate maturing and striga resistant varieties as well as a local variety $\mathrm{HH}$ that is commonly grown in the area which is used as a local check in the experiment. The experiment was conducted at the Kano University of Science and Technology Wudil teaching and research farm (Bagauda, the former ICRISAT research station and L.I.B.C Gaya) during the 2010 and 2011 rainy seasonswith four levels of $\mathrm{N}$-fertilizers: $0 \mathrm{~kg} / \mathrm{ha}$, $80 \mathrm{~kg} / \mathrm{ha}, 100 \mathrm{~kg} / \mathrm{ha}$, and $120 \mathrm{~kg} / \mathrm{ha}$ ). 
The experiment was laid in randomized complete block design, with twenty treatments and three replications. The treatment consisted of five (5) varieties of maize and four (4) levels of Nitrogen fertilizer $\left(R_{1} 0, R_{2} 80, R_{3} 100\right.$, and $\left.R_{4} 120\right)$, making a total of 20 treatments.

The area of each plot consists of four rows of five meters $(5 \mathrm{~m})$ long with $75 \mathrm{~cm}$ between the rows and $3 \mathrm{~m}$ wide resulting in $15 \mathrm{~m}^{2}$ with total of 60 plots, with the plant densities averaging 40.000 plants/ha in the whole experiment.

The land was ploughed and harrowed which was followed by ridging. The ridges were later marked out for plots, discards and pathways. Ridges were remolded at 5 WAS to prevent stalk and root lodging. After rain was fully established, the seeds were sown the same day at the spacing $(75 \mathrm{~cm} \times 25 \mathrm{~cm})$ inter and intra row respectively.

Nitrogen was applied at four (4) different rates of $0 \mathrm{kgN}, 80 \mathrm{KgN}, 100 \mathrm{KgN}$, and $120 \mathrm{KgN}$, using N.P.K 20:10:10 compound fertilizer first application was done at two WAS and second at six WAS.

Data for quantitative characters were collected from the net plot for the following parameters:
1. Plant height
2. ear height
3. No of ears/plant
4. cob length
5. number of rows per cob
6. number of seed per cob
7. Weight of 100 seed

The collection of data started at the time of crop maturity, considering the three middle rows of each plot..

Plant height. This was measured from the soil surface to the lowest branch of tassel of ten randomly selected samples from the middle rows of each plot.

Ear height. Was measured from the soil surface to the first ear node of ten randomly sampled plants from the middle rows of each plot.

All the data were analysed using analysis of variance (ANOVA) procedure in the statistical software package GENSTAT. The comparisons of the treatment means were made using the Duncan's multiple range test $(p<0.05)$.

Four plants were selected at random from each plot at harvest for measurement and observation. Phenotypic, genotypic and environmental variances were computed from the respective mean squares. Broad-sense heritability for each trait was calculated as the ratio of the genotypic variance to phenotypic variance. Treatments of means were compared using DMRT, Pearson's correlation were taken to determine the types of associations between some characters and grain yield of maize. The variance of the observed values of phenotypic variance $(\mathrm{Vp})$, was partitioned into different components:

$\mathrm{Vp}=\mathrm{VG}+\mathrm{VE}$.

Heritability ( $\mathrm{H} \%)$ was estimated as:

$H_{B}^{2}=\sigma_{g}^{2} / \sigma_{g}^{2}+\sigma_{e}^{2} / r$
Where: $\sigma^{2} g=$ total genetic variance; $\sigma^{2} e=$ environmental variance (Sprague, 1967):

\section{RESULTS}

\section{Stand Count at harvest}

Table 1 shows the influence of variety and nitrogen level on stand count at harvest of maize. The performance of the varieties was significantly $(P \leq$ 0.05 ) different in relation to stand count at harvest, Sammaz 18 produced significantly $(P \leq 0$. the highest stand count. This was followed by Sammaz 17, sammaz 18 and $\mathrm{HH}$ which were at par, the least stand count was produced by sammaz 20 . The influence of Nitrogen levels with regard to stand count at harvest was not statistically significant. The interaction between variety and Nitrogen level was also not significant.

\section{Plant height}

Table 2 shows the effect of variety and nitrogen level in relation to plant height at harvest. The performance of variety in relation to plant height was significant $(P$ $\leq 0.05$ ). The tallest plant was produced by $\mathrm{HH}$. This was followed by Sammaz 17. Sammaz 18 produced the next tallest plants after sammaz 17 . The shortest plants were produced by Sammaz 20 and Sammaz 28 which were at par. The effect of Nitrogen level on plant height was statistically significant $(P \leq 0.05)$, the tallest plant was produced by the application of $80 \mathrm{~kg} / \mathrm{ha}$ of nitrogen, this was followed by the application of $100 \mathrm{~kg} / \mathrm{ha}$ and $120 \mathrm{~kg} / \mathrm{ha}$ of nitrogen which were at par. The least plant height was produced by the controlled condition which was $0 \mathrm{~kg} / \mathrm{ha}$ of nitrogen. The interaction between variety and nitrogen level was not statistically significant.

\section{Ear height}

Table 3 shows the effect of variety and nitrogen level on ear height at the time of harvest. The performance of varieties in relation to ear height showed that the largest ear height was significantly $(P \leq 0.05)$ obtained in sammaz 17 and $\mathrm{HH}$ which were at par, followed by sammaz 18 and sammaz 20 that were also at par, while the least ear height was recorded in sammaz 18. The effect of nitrogen levels on ear height was not statistically different. Also the interaction among variety and nitrogen levels was not significant.

\section{Number of ears per plant}

Table 4 shows the effect of variety and nitrogen level on number of cobs per plant at harvest. The effect of the varieties was significantly different $(P \leq 0.05)$, Sammaz 18 and Sammaz 20 which were at par produced the highest number of cobs. This was followed by Sammaz 17 and Sammaz 28 which were at par. The least number of cobs per plant was produced by $\mathrm{HH}$. The influence of nitrogen levels with regards to number of cobs per plant at harvest was not statistically significant. The interaction between variety and nitrogen level was not significant. 


\section{Weight of 100 seed}

Table 5 shows the effect of variety and nitrogen rate in relation to weight of 100 seed. Sammaz 28 produced significantly $(P \leq 0.05)$ heavier seeds. This was followed by Sammaz 20 and $\mathrm{HH}$ which are at par. Sammaz 17 and sammaz 18 which were at par produced the least weight of 100 seed. The effect of Nitrogen levels on weight of 100 seeds was statistically insignificant. The interaction between variety and nitrogen level was not significant.

\section{Grains weight per plot}

Table 6: shows the influence of variety and nitrogen level in relation to grains weight per plot. The varieties performed significant $(P \leq 0.05)$ different in term of grains weight per plot. Sammaz 20 and Sammaz 28 which were at par performed better in terms of grain weight. This was followed by Sammaz 18, $\mathrm{HH}$ produced the next grain yield after sammaz 18 . The least yield was obtained from sammaz 17.

The influence of Nitrogen levels on varieties was significant $(\mathrm{P}<0.05)$. The application $100 \mathrm{~kg} \mathrm{~N} / \mathrm{ha}$ and $120 \mathrm{~kg} \mathrm{~N} / \mathrm{ha}$ produced the highest grain weight per plot after $80 \mathrm{~kg} \mathrm{~N} / \mathrm{ha}$. The least yield was obtained by the application of $0 \mathrm{~kg} \mathrm{~N} / \mathrm{ha}$. The interaction between varieties and Nitrogen levels was not statistically significant.

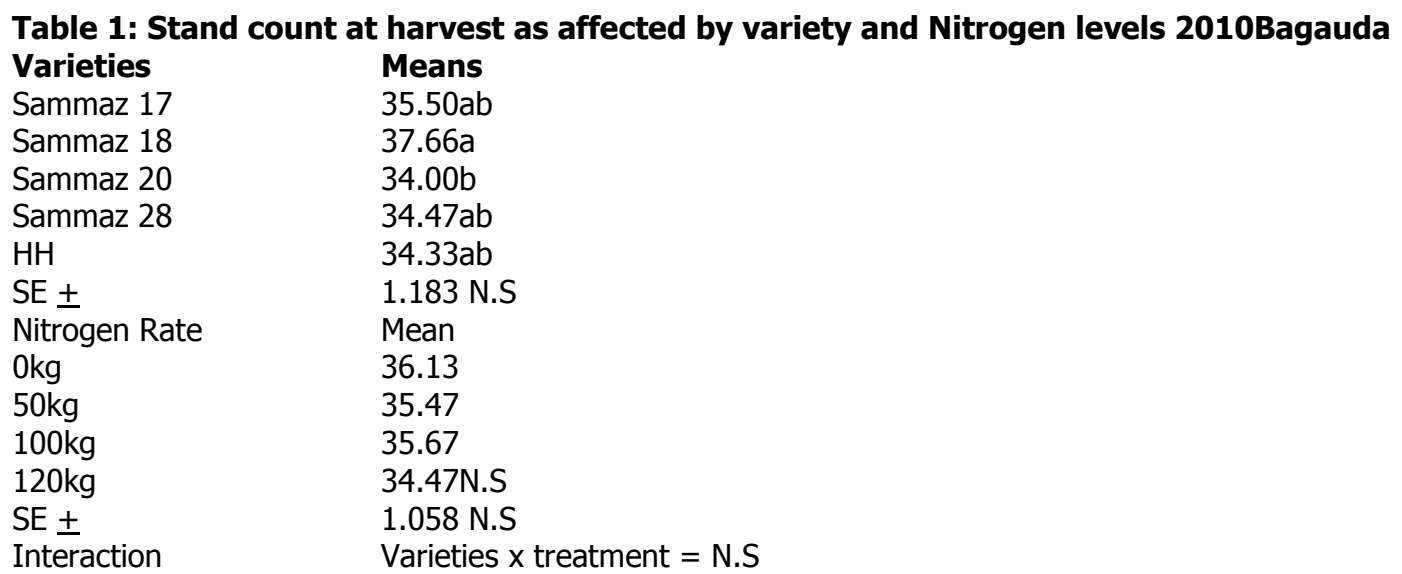

Means followed by the same letter(s) within the same column and treatment are not significantly different using DMRT, Where NS = Not significant

Table 2(a): Plant height at harvest as affected by variety and Nitrogen levels 2010

$\begin{array}{ll}\text { Varieties } & \text { Means } \\ \text { Sammaz } 17 & 232.80 \mathrm{ab} \\ \text { Sammaz } 18 & 215.44 \mathrm{bc} \\ \text { Sammaz 20 } & 204.53 \mathrm{c} \\ \text { Sammaz } 28 & 204.35 \mathrm{c} \\ \mathrm{HH} & 249.03 \mathrm{a} \\ \mathrm{SE} \pm & 8.877 \\ \mathrm{Nitrogen} \text { Rate } & \text { Mean } \\ \text { Okg } & 208.40 \mathrm{~b} \\ 50 \mathrm{~kg} & 234.28 \mathrm{a} \\ 100 \mathrm{~kg} & 217.38 \mathrm{ab} \\ 120 \mathrm{~kg} & 224.85 \mathrm{ab} \\ \text { SE } \pm & 7.939 \mathrm{~N} . \mathrm{S} \\ \text { Interaction } & \text { Varieties } \times \text { treatment N.S }\end{array}$

Means followed by the same letter(s) within the same column and treatment are not significantly different using DMRT, Where NS = Not significant

Table 2(b): Plant height at harvest as affected by variety and Nitrogen levels 2011

\begin{tabular}{llllll}
\hline $\begin{array}{l}\text { Variety/ } \\
\text { Nitrogen }\end{array}$ & Sammaz 17 & Sammaz 18 & Sammaz 20 & Sammaz 28 & HH \\
\hline 0 & $91.60 \mathrm{c}$ & $89.50 \mathrm{c}$ & $84.1 \mathrm{c}$ & $83.4 \mathrm{c}$ & $86.8 \mathrm{c}$ \\
50 & $109.4 \mathrm{~b}$ & $98.4 \mathrm{bc}$ & $96.8 \mathrm{bc}$ & $93.3 \mathrm{bc}$ & $107.5 \mathrm{~b}$ \\
100 & $125.1 \mathrm{a}$ & $118.1 \mathrm{a}$ & $112.5 \mathrm{~b}$ & $105.0 \mathrm{~b}$ & $129.6 \mathrm{a}$ \\
120 & $119.0 \mathrm{a}$ & $120.1 \mathrm{a}$ & $113.1 \mathrm{~b}$ & $129.1 \mathrm{a}$ & $109.8 \mathrm{~b}$ \\
\hline
\end{tabular}

SED $=8.5$ N.S

Means followed by the same letter(s) within the same column and treatment are not significantly different using DMRT, Where, N.S = Not significant 
Table 3(a): Ear height of maize plant as affected by variety and Nitrogen2010

Varieties

Sammaz 17

Sammaz 18

Sammaz 20

Sammaz 28

$\mathrm{HH}$

$\mathrm{SE} \pm$

Nitrogen Rate

$0 \mathrm{~kg}$

$50 \mathrm{~kg}$

$100 \mathrm{~kg}$

$120 \mathrm{~kg}$

$\mathrm{SE} \pm$

Interaction

Means followed by the same letter(s) within the same column and treatment are not significantly different using

DMRT, Where $* \quad=\quad$ Significant at $1 \%$ level of probability, NS $\quad=\quad$ Not significant

Table 3(b): Ear height of maize plant as affected by variety and Nitrogen 2011

\begin{tabular}{|c|c|c|c|c|c|}
\hline $\begin{array}{l}\text { Variety/ } \\
\text { Nitrogen }\end{array}$ & Sammaz 17 & Sammaz 18 & Sammaz 20 & Sammaz 28 & $\mathrm{HH}$ \\
\hline 0 & $14.20 \mathrm{c}$ & $13.40 \mathrm{c}$ & $13.03 c$ & $12.20 \mathrm{c}$ & $13.63 c$ \\
\hline 50 & $22.32 b$ & $21.07 \mathrm{c}$ & $18.40 \mathrm{bc}$ & $15.82 \mathrm{c}$ & $19.80 \mathrm{bc}$ \\
\hline 100 & $30.20 a$ & $27.30 \mathrm{~b}$ & $19.93 b c$ & $19.30 \mathrm{bc}$ & $32.17 a$ \\
\hline 120 & $28.80 \mathrm{a}$ & $26.40 \mathrm{ab}$ & $26.62 a$ & $35.25 a$ & $24.43 b$ \\
\hline
\end{tabular}

SED=10.3 Significant

Means followed by the same letter(s) within the same column and treatment are not significantly different using DMRT, Where, N.S = Not significant

Table 4: Number of ears per plant as affected by variety and Nitrogen levels 2010

\begin{tabular}{ll}
\hline Varieties & Means \\
\hline Sammaz 17 & $1.25 \mathrm{ab}$ \\
Sammaz 18 & $1.38 \mathrm{a}$ \\
Sammaz 20 & $1.33 \mathrm{a}$ \\
Sammaz 28 & $1.29 \mathrm{ab}$ \\
$\mathrm{HH}$ & $1.07 \mathrm{~b}$ \\
$\mathrm{SE} \pm$ & $0.080 \mathrm{~N} . \mathrm{S}$ \\
Nitrogen Rate & Mean \\
Okg & 1.23 \\
$50 \mathrm{~kg}$ & 1.23 \\
$100 \mathrm{~kg}$ & 1.22 \\
$120 \mathrm{~kg}$ & 1.38 \\
SE \pm & $0.072 \mathrm{~N} . S$ \\
Interaction & Varieties x treatment N.S \\
\hline
\end{tabular}

Means followed by the same letter(s) within the same column and treatment are not significantly different using DMRT, Where NS = Not significant

Table 5: Weight of 100 seeds as affected by variety and Nitrogen levels 2010

\begin{tabular}{ll}
\hline Varieties & Means \\
\hline Sammaz 17 & $16.66 \mathrm{~b}$ \\
Sammaz 18 & $18.28 \mathrm{~b}$ \\
Sammaz 20 & $19.59 \mathrm{ab}$ \\
Sammaz 28 & $21.43 \mathrm{a}$ \\
$\mathrm{HH}$ & $18.88 \mathrm{ab}$ \\
$\mathrm{SE} \pm$ & $1.064^{*}$ \\
Nitrogen Rate & Mean \\
Okg & 19.40 \\
$50 \mathrm{~kg}$ & 19.67 \\
$100 \mathrm{~kg}$ & 18.49 \\
$120 \mathrm{~kg}$ & 18.32 \\
SE \pm & $0.95 \mathrm{~N} . S$ \\
Interaction & Varieties x treatment N.S \\
\hline
\end{tabular}

Means followed by the same letter(s) within the same column and treatment are not significantly different using DMRT, Where $* \quad=\quad$ Significant at $1 \%$ level of probability, NS $=\quad$ Not significant 
Table 6: Grain weight per plot as affected by variety and Nitrogen level 2010

\begin{tabular}{ll}
\hline Varieties & Means \\
\hline Sammaz 17 & $1.62 \mathrm{c}$ \\
Sammaz 18 & $2.28 \mathrm{ab}$ \\
Sammaz 20 & $2.46 \mathrm{a}$ \\
Sammaz 28 & $2.65 \mathrm{a}$ \\
$\mathrm{HH}$ & $1.68 \mathrm{bc}$ \\
$\mathrm{SE} \pm$ & $0.214^{* *}$ \\
$\mathrm{Nitrogen}$ Rate & Mean \\
Okg & $1.83 \mathrm{~b}$ \\
$50 \mathrm{~kg}$ & $2.50 \mathrm{~b}$ \\
$100 \mathrm{~kg}$ & $2.07 \mathrm{ab}$ \\
$120 \mathrm{~kg}$ & $2.15 \mathrm{ab}$ \\
$\mathrm{SE} \pm$ & $0.192 \mathrm{~N} . \mathrm{S}$ \\
Interaction & Varieties $x$ treatment N.S \\
\hline
\end{tabular}

Means followed by the same letter(s) within the same column and treatment are not significantly different using DMRT, Where $^{* *}=\quad$ Significant at $5 \%$ level of probability, NS $=\quad$ Not significant

Table 7.Phenotypic variation, genotypic variation, heritability, phenotypic coefficient of variation and genotypic coefficient of variation

\begin{tabular}{|c|c|c|c|c|c|c|}
\hline Characters & $\begin{array}{c}\text { Phenotypic } \\
\text { Variation }\end{array}$ & $\begin{array}{l}\text { Genotypic } \\
\text { Variation }\end{array}$ & $\begin{array}{l}\text { Environmental } \\
\text { Variance(BS) }\end{array}$ & Heritability & $\begin{array}{l}\text { Ph. coef.,\% } \\
\text { Variation }\end{array}$ & $\begin{array}{l}\text { Ge. coef.,\% } \\
\text { Variation }\end{array}$ \\
\hline plant height & 0.92 & 0.69 & 0.21 & 0.79 & 1.72 & 1.77 \\
\hline Ear height & 0.35 & 0.42 & 0.15 & 0.43 & 0.93 & 1.05 \\
\hline No. of ears/plant & 0.000056 & 0.000003 & 0.000062 & 0.07 & 0.18 & 0.69 \\
\hline 100 grain weight & 2.67 & 2.35 & 0.69 & 0.81 & 7.89 & 8.53 \\
\hline Grain yield & 71.25 & 47.52 & 36.13 & 0.78 & 6.23 & 5.33 \\
\hline
\end{tabular}

\begin{tabular}{ll}
\hline BS & Broad sense \\
Ph.coef.,\% & Phenotypic coefficient of variation, \% \\
Ge.coef.,\% & Genotypic coefficient of variation, \%
\end{tabular}

\section{DISCUSSION}

Analysis of variance for plant height, ear height, number of ears per plant, weight of 100 grain and grain yield showed highly significant differences among varieties

Table 3 shows the interaction between nitrogen levels and ear height of the different maize varieties. The highest means were obtained at the fertilizer rates of $50 \mathrm{~kg} / \mathrm{ha}$ and $100 \mathrm{~kg} / \mathrm{ha}$, and the least values were recorded for $0 \mathrm{~kg} / \mathrm{ha}$. Khalifa et al. (1984) and Gozubenli et al. (2001) also recorded similar findings. The genotypic variance, environmental variance, genotypic coefficient of variation, phenotypic coefficient of variation and Broad-sense heritability were high indicating sufficient genetic variability in total phenotypic variation and suggest the possibility of selection for these traits (Nagoli,1983)

Analysis of variance for plant height revealed highly significant differences among varieties. The genotypic variance was smaller than the phenotypic variance and both these variances were greater than the environmental variance genotypic coefficient of variation $(1.67 \%)$ was smaller than the phenotypic coefficient of variation (1.72\%). The estimate of broad-sense heritability was high (0.79) thus showing the presence of considerable amount of genetic variation in total phenotypic variation.

Analysis of variance for ear height showed highly significant differences among varieties. The genotypic variance was smaller than the phenotypic variance and both these variances were greater than the environmental variance genotypic coefficient of variation $(0.93 \%)$ was smaller than the phenotypic coefficient of variation (1.05\%). The estimate of broad-sense heritability was high (0.49) indicating the presence of considerable amount of genetic variation in total phenotypic variation. The results confirmed the findings of other researchers on high heritability for plant height (El-Nagouliet al., 1983 and Pal et al., 1986)).

Number of ears per plant showed nonsignificant differences among varieties of maize. Genotypic variance was smaller than the environmental variance as well as from the phenotypic variance. Genotypic coefficient of variation was low $(0.19 \%)$ than the phenotypic Coefficient of variation $(0.68 \%)$. Broad-sense heritability was very low (0.07) , this is indication that selection for this trait will not be effective.

Analysis of variance for 100-grain weight (Table 7) showed highly significant differences among the all the varieties. Genotypic variance was greater than the environmental variance (Table 8). Genotypic coefficient of variation was smaller $(7.89 \%)$ than the phenotypic coefficient of variation (8.59\%). The estimate of broad sense heritability (0.81) was observed to be moderate. This agreed with the findings of Rea, R. A.et., al (2007)

Analysis of variance for grain yield per plot revealed highly significant differences among the varieties. Genotypic variance was greater than the environmental variance. Genotypic coefficient of variation $(5.33 \%)$ was smaller than the phenotypic Coefficient of variation (6.24\%). The estimate of broad sense heritability $(0.78)$ was moderately high. 


\section{CONCLUSION}

Field experiments on heritability of some quantitative characters in five different varieties of maize, under the influence of various rate of nitrogen were conducted at the Research farm of Kano University of Science and Technology Wudil, during 2010 and 2011rainy seasons. The experiment was aimed at establishing the variability of some quantitative characters which could be used to estimate the heritability of ear height for mechanized harvesting breeding programme in maize. Highly significant differences were observed among all the 5 varieties for all the traits except for number of ears per plant

\section{REFERENCES}

Azanza, F., Avri Bar-Zur and J. A. Juvik (1996).Variation in sweet corn.kernel characteristics associated with stand establishment and eating quality. Euphytica. 87:7-18.

El-Nagouli, O.O., M.A.A. Fadi, A.A. Ismail and M. Khamis, (1983).Genotypic and phenotypic correlations and path analysis in maizeand their implications selection.Agron.Abst.Amer. Soc. Agron.,62-3 [Pl. Br. Abst., 54: 886; 1984].

Eltahir, S. A., G. B. Saleh. Z. B. Wahab and A. A. Rahim (2003).Performance.heritability and correlation studies on varieties and population cross of sweet corn. Asian Journal of Plant Sciences. 2:756-760.

Gozubenli H, Ulger AC, Sener O (2001), The effects of different nitrogen doses on grain yield and yield related characters of some maize genotypes grown as second crop.(in turkish) J Agric Fac. C. U., 16(2):39-48.

Has, V. (2007).Genetic analysis of some yield components and kernel quality in sweet corn.Recent Progress in Medicinal Plants.Natural Products II. (India). Studium Press LLC. U.S.A. 18:437-452.

Khalifa M A, Shokres E S, El-sseyed K I (1984): Effect of nitrogen and plant population levels in where it was non-significant. Therefore, the discovery of genetic variability of different maize quantitative characters can be significantly altered by selection. Hence an auspicious selection and breeding for these traits is facilitated by the abundant genetic variability found in it.

\section{Acknowledgement}

Our special gratitude goes to the Maize Breeding Unit, Department of Plant Science, Ahmadu Bello University Zaria for providing us with improved seeds used in this research.

yield of maize cultivars. J. Res. Punjab Agric. Univ. 23(4):544-548.

Kumari, J., R. N. Gadag and G. K. Jha (2006). Heritability and correlation studies in sweet corn for quality traits, field emergence and grain yield. MNL 80: 18-19.

Nigussie, M. and G. Saleh (2007).Genetic variability and heritability within sweet corn (Zea mays L. saccharata) breeding populations. Malaysian Applied Biology 36:15-20.

Pal, S.S., A.S. Khehra and B.S. Dhillon, 1986. Genetic analysis andselection advance in maize population. Maydica, 31: 153-62 [P/. Br.Abst., 57: 1100; 1987].

Rea, R. A., C. E. Watson and F. M. Davis (2007). Heritability and correlation among some selected morphological traits and their relationship with fall armyworm damage in sweet corn. J. Econ Entomol. 100(6):18871895

Sujiprihati, S., M. Syukur and R. Yunianti (2005).Estimation of genetic variability and heritability of some vegetative characters and yield of sweet corn.JurnalAgrotropika (Indonesia) 10(2):75-78.

Steel, R.G.D. and J.H. Torrie, (1980). Principles and Procedures of Statistics; $A$ Biometrical Approach.McGraw Hill Book Co., Inc., New York. 